\title{
ランタン膜の水素化・脱水素化に伴う構造変化
}

\author{
前田 幹 雄 $1, *$ 越後谷淳—2 山口 明 2 \\ 1岩手大学大学院工学研究科物質工学専攻 \\ 2岩手大学工学部材料物性工学科
}

J. Japan Inst. Metals, Vol. 68, No. 9 (2004), pp. 776-780

(C) 2004 The Japan Institute of Metals

\section{The Structural Change of Lanthanum Thin Films by Hydrogenation and Dehydrogenation}

\author{
Mikio Maeda ${ }^{1, *}$, Jun-ichi Echigoya ${ }^{2}$ and Akira Yamaguchi ${ }^{2}$ \\ ${ }^{1}$ Department of Materials Science, Graduate School of Engineering, Iwate University, Morioka 020-8551 \\ ${ }^{2}$ Department of Materials Science and Engineering, Faculty of Engineering, Iwate University, Morioka 020-8551
}

\begin{abstract}
Structural change in hydrogenation and dehydrogenation processes of La films was investigated. La/Pd films were produced at substrate temperatures of $300 \mathrm{~K}-573 \mathrm{~K}$ on a $\mathrm{SiO}_{2}$ substrate using magnetron-sputtering equipment. $\mathrm{La} / \mathrm{Pd}$ films were hydrogenated under a pressure of $1.0 \times 10^{5} \mathrm{~Pa}$ in a vacuum chamber. Phase transition from La to $\mathrm{LaH}_{x}(2<x<3)$ by hydrogenation resulted in a 6 - to 10 -fold increase of resistivity. Hydrogenation and dehydrogenation readily occurred near room temperature for $\mathrm{La} / \mathrm{Pd}$ films. The ratio of the growth direction of [0001] to [1010] changed with substrate temperature in the as sputtered La films. When the growth direction of La film was [1010], the rate of hydrogenation became slow in comparison with that of [0001]. The direction of the La films changed to the [111] direction of $\mathrm{LaH}_{x}$ after hydrogenation, though the initial directions of La films were [0001] and [1010]. The processes of hydrogenation and dehydrogenation may affect oxygen which remains inside the La films. In dehydrogenation at room temperature, $\mathrm{LaH}_{x}(2<x<3)$ was transformed to $\mathrm{LaH}_{2}$, but not to $\mathrm{La}$.
\end{abstract}

(Received April 22, 2004; Accepted July 6, 2004)

Keywords: rare-earth, thin-film, lanthanum, $L_{a} H_{x}$, sputtering, hydrogenation, electron spectroscopy for chemical analysis, phase transition

\section{1. 緒言}

1996 年, Huiberts らは Y や La の薄膜は水素化-脱水素化 によって可逆的に金属一半導体遷移を起こし，それに伴い可 視光域での光透過率が変化することを示した ${ }^{1-3)}$. この希土 類金属を薄膜にする方法は, 水素と希土類金属が反応して構 造変化が起きても粉末化することが無く, また反応速度が速 いなどの利点があり各種センサーへの応用が考えられる.

$\mathrm{Y}$ では水素化が進行することにより $\alpha$ 相 $\left(\mathrm{YH}_{x}: 0 \leqq x<\right.$ $0.21: \mathrm{hcp}), \alpha+\beta$ 相 $\left(\mathrm{YH}_{x}: 0.21 \leqq x<1.83\right), \quad \beta$ 相 $\left(\mathrm{YH}_{x}: 1.83\right.$ $\leqq x<2.09$ : fluorite fcc $), \beta+\gamma$ 相 $\left(\mathrm{YH}_{x}: 2.09 \leqq x<2.85\right)$ そし $\tau \gamma$ 相 $\left(\mathrm{YH}_{x}: 2.85 \leqq x<3:\right.$ hcp $)$ と呼ばれる水素化物相に連続 的に相変態を起こす. $\alpha+\beta$ 相から $\beta$ 相 $(x \geqq 1.83)$ 乞相変態 が進行すると, 電気抵抗は増加し, $\gamma$ 相 $(x \geqq 2.85)$ で電気抵 抗はほぼ一定となると同時に可視光域に打ける光透過率の劇 的な変化が観察され，それまで金属色をして光を吸収してい た状態から黄色をした透明なものに変化する ${ }^{4,7,8)}$. この電気 抵抗の大きな変化が起こる現象は金属-半導体遷移に起因し ている. しかし通常の水素 1 気圧下では $\mathrm{YH}_{x}$ は $x=2.85$ ま での水素化物しか形成されない3,8,9). 化学量論比が成り立つ $\mathrm{YH}_{x}(x=3)$ となるためには数百気圧のきわめて高い圧力が必

\footnotetext{
* 岩手大学大学院生 (Graduate Student, Iwate University)
}

要である3).

$\mathrm{La}$ \& $\mathrm{Y}$ と同様に水素化が進行するにしたがい， $\alpha$ 相 $\left(\mathrm{LaH}_{x}: 0 \leqq x<0.01: \mathrm{hcp}\right), \alpha+\beta$ 相 $\left(\mathrm{LaH}_{x}: 0.01 \leqq x<2\right)$ そして $\beta$ 相 $\left(\mathrm{LaH}_{x}: 2 \leqq x<2.85\right.$ : fluorite fcc $)$ と相変態が起きる. $\mathrm{LaH}_{x}$ は $x=2$ から $\mathrm{CaF}_{2}$ 構造となる.さらに水素が $\mathrm{La}$ に導 入されると, 八面体位置に水素が配置する構造となり $\mathrm{BiF}_{3}$ 構造となる. $\mathrm{LaH}_{x}$ の $x$ の值が増加するにしたがい $\left(\mathrm{LaH}_{x}: 2\right.$ $<x<3)$ 格子定数は小さくなり $\left(\mathrm{LaH}_{2.0}: a=0.566 \mathrm{~nm}\right.$, $\left.\mathrm{LaH}_{2.39 \sim 2.5}: a=0.563 \mathrm{~nm}, \mathrm{LaH}_{3}: a=0.560 \mathrm{~nm}\right), x=2.85$ 付近 で金属一半導体遷移が起こる5,6). それに伴い可視光域での光 透過率が変化し, $\operatorname{LaH}_{x}(x=2.85)$ では赤みがかった透明な状 態になる ${ }^{4,9,10)}$. これら希土類金属が持つ特有な現象は物理 的にも興味がもたれ，この水素に対する反応を利用すること による水素センサーへの応用が考えられる. しかし希土類金 属薄膜の構造と水素の吸収・放出過程の関係はこれまで良く 知られていない。 また, $\mathrm{La}$ から $\mathrm{LaH}_{x}$ へと相変態に打いて La の結晶方位があたえる相変化の速度についても知られて いない.

そこで本研究ではスパッタリング法により作製した La 薄 膜を用いて水素吸収・放出過程について研究を行ったＬ La 薄膜作製時の基板温度を变化させることにより起こる成長組 織の変化とそれに伴う水素吸収・放出過程への影響を調べる ことを目的とする. 


\section{2. 研 究 方 法}

$\mathrm{La}$ 薄膜は高周波マグネトロンスパッタリング装置を用い て作製した。スパッタリングを行う前の真空チャンバーの初 期真空度は $3.0 \times 10^{-5} \mathrm{~Pa}$ であった. La 膜と石英ガラス基板 の剥離を防ぐため, スパッタリングガス圧力を調節して La 膜を作製した. La のスパッタリングには直径 $50 \mathrm{~mm}$, 純度 99.99\%の La ターゲットを使用した. 石英ガラス基板上に La を $300 \mathrm{~nm}$ 蒸着させた. 希土類金属膜の酸化を防ぐ保護 膜および水素を水素イオンと電子に乘離させる触媒として $\mathrm{Pd}$ を $20 \mathrm{~nm}$ の厚さで La膜上に蒸着した．Pdのスパッタリ ングには直径 $50 \mathrm{~mm}$, 純度 $99.99 \%$ の $\mathrm{Pd}$ ターゲット使用し た. スパッタリング出力は $\mathrm{La}, \mathrm{Pd}$ とも $50 \mathrm{~W}$ とした. La膜 を蒸着させる際に赤外線ランプヒーターを使用し, 基板温度 を $300 \mathrm{~K}, 373 \mathrm{~K}, 473 \mathrm{~K}, 573 \mathrm{~K}$ と変化させた. La と Pd の合 金化を防ぐ為, La 膜を $320 \mathrm{~K}$ まで冷却後, その上に Pdを 蒸着した。 以下この膜を $\mathrm{La} / \mathrm{Pd}$ 膜と表記する。作製した $\mathrm{La} / \mathrm{Pd}$ 膜は他の容器に移して $1.0 \times 10^{2} \mathrm{~Pa}$ の圧力まで真空に した後, $1.0 \times 10^{5} \mathrm{~Pa}$ の水素ガス中で室温に括いて水素化し た. その過程で四探針法を用いた電気抵抗率測定を行った. 水素化した後, 再び $1.0 \times 10^{2} \mathrm{~Pa}$ の圧力まで真空にすること により脱水素化過程についても電気抵抗率測定を行った. 室 温に損いて再び水素化を行い電気抵抗率が一定になったこと を確認し, 試料を容器から取り出した.この試料について $170 \mathrm{~K}$ から $323 \mathrm{~K}$ までの温度範囲で電気抵抗率測定を行 い, 電気抵抗率の温度依存性を調べた. また水素化前後の試 料について JASCO 製 V-570DS を使用し光透過率測定,

MacScience 製 M03XHF22 を使用しX 線回折測定, ULVAC-PHI 製 ESCA5600CIM 使用し X 線光電子分光測定を 行った.

\section{3. 結果および考察}

Fig. 1 に基板温度をそれぞれ $300 \mathrm{~K}, 373$ K, 473 K, 573 K に保ってスパッタリングを行った場合の $\mathrm{La} / \mathrm{Pd}$ 膜の X 線回 折パターンを示す。いずれの基板温度においても $\mathrm{La}$ (100) ・ (002) および $\operatorname{Pd}(111)$ の反射が観察された. 基板温

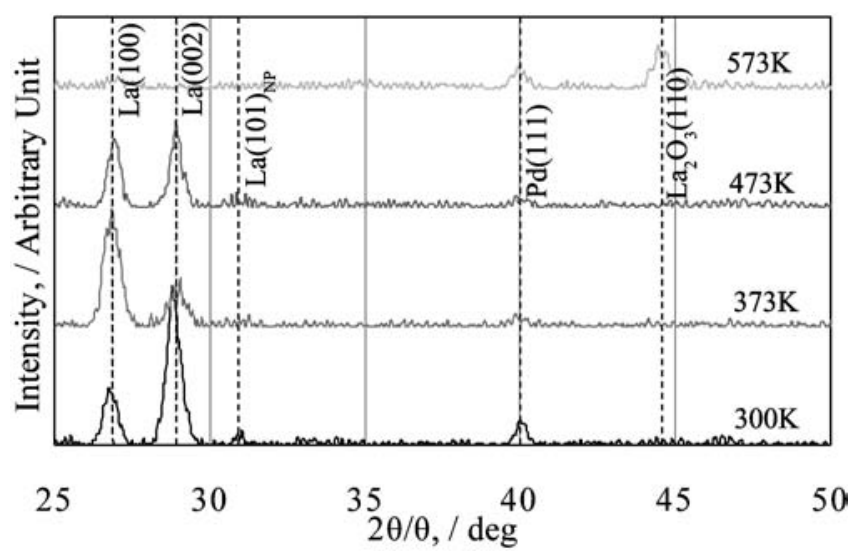

Fig. 1 X-ray diffraction patterns of La/Pd films deposited on substrates at temperatures of $300 \mathrm{~K}, 373 \mathrm{~K}, 473 \mathrm{~K}$ and $573 \mathrm{~K}$.
度 $300 \mathrm{~K}$ の試料では $\mathrm{La}(002)$ の反射が強く現れていた．基 板温度を $373 \mathrm{~K}$ にした試料では, La (002)の反射に比べ $\mathrm{La}(100)$ の反射が強く現れた. 基板温度 $473 \mathrm{~K}$ の試料も同様 であった。基板温度 $573 \mathrm{~K}$ 度の試料においては基板温度 $473 \mathrm{~K}$ 以下の試料に比べて異なる新たなピークが現れた．こ の新たなピークは $\mathrm{La}_{2} \mathrm{O}_{3}(110)$ のピークであった. どの基板 温度に括いても強度の弱い $\mathrm{La}(101)$ の反射が現れた. 以上

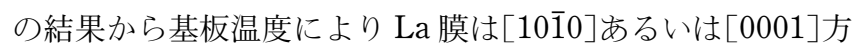
向に優先方位を持って成長していることがわかった． $573 \mathrm{~K}$ 以上の試料では酸化物が生成されることから $573 \mathrm{~K}$ の試料 は使用しないこととした。

Fig. 2 に基板温度 $300 \mathrm{~K}, 373 \mathrm{~K}$ そして $473 \mathrm{~K}$ の La/Pd 膜 を $1.0 \times 10^{5} \mathrm{~Pa}$ の水素ガス雾囲気中で水素化したときの電気 抵抗率の時間変化を示す. 水素を導入し始めた時間を 0 と した. いずれの試料に拈いても水素を導入することにより電 気抵抗率が増加し, 時間が経つにつれ一定になった. 電気抵 抗率は水素化前の值と比較し，6〜10 倍増加した. 基板温度 $300 \mathrm{~K}$ の試料は，水素を導入すると同時に急激な電気抵抗率 の増加が見られた．基板温度 $373 \mathrm{~K}$ の試料は電気抵抗率の 時間変化が緩やかであった. 基板温度 $473 \mathrm{~K}$ の試料は基板 温度 $373 \mathrm{~K}$ の場合と比べ電気抵抗率が一定になるまでの時 間が短縮していた。

Fig. 3 に $\mathrm{LaH}_{x}(x \geqq 2) / \mathrm{Pd}$ 膜の広範囲 $\mathrm{X}$ 線回折パターンを 示す. いずれも試料とも水素化が完了したことを電気抵抗率 から確認し, 容器から試料を取り出した. 取り出した試料を すぐに液体窒素を使用して冷却し水素の放出を防ぎながら $\mathrm{X}$ 線回折測定を行った. どの基板温度の試料においても La (100)・(002)の反射が消え, $\mathrm{LaH}_{2}(111)$ の反射が強く現れ た.しかし $\mathrm{LaH}_{2}(111)$ と $\mathrm{LaH}_{x}(111)(2<x<3)$ のピークが出 現する角度が $27 \sim 27.5$ 度付近と非常に近いために重なって いると考えられる. 基板温度 $300 \mathrm{~K}, 473 \mathrm{~K}$ の試料では $\mathrm{LaH}_{2}(200)$ の反射も非常に弱いが観察された.このことは水 素化前の La 結晶の優先方位が $[10 \overline{1} 0],[0001]$ 方位でも, 水 素化後の La 水素化物の大部分は[111]方向になっているこ とを示している.

Fig. 4 に Fig. 1 から求められる La (100)+ (002)に対する $\mathrm{La}(002)$ の反射強度比を示す. Fig. 2 の結果から水素化に伴 って非常に早い電気抵抗率の変化を示す基板温度 $300 \mathrm{~K}$ の

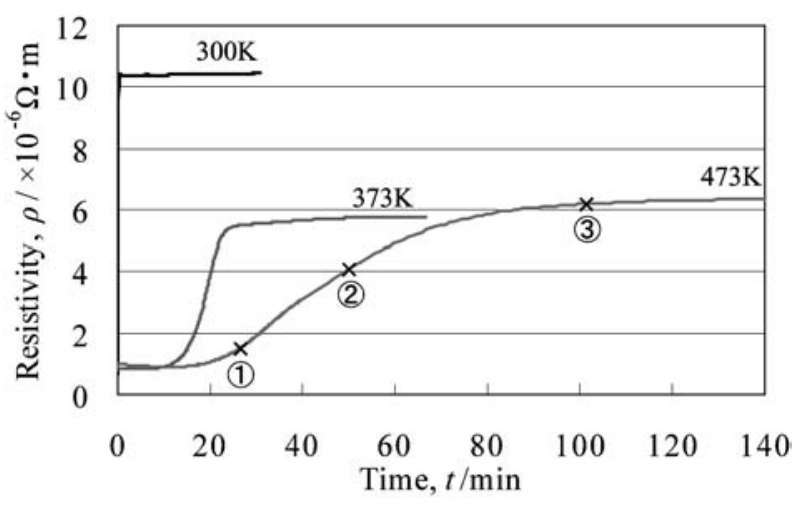

Fig. 2 Resistivity change during hydrogen loading $\left(P_{\mathrm{H}_{2}}=1.0\right.$ $\times 10^{5} \mathrm{~Pa}$ ) of a La/Pd film at room temperature as a function of time. 
試料では La 膜において $\mathrm{La}(002)$ は約 75\%占めていた。 た非常に緩やかな電気抵抗率の变化を示す基板温度 $373 \mathrm{~K}$ の試料では $\mathrm{La}$ 膜で $\mathrm{La}(002)$ が占める割合は約 $25 \%$ である. La は水素化に伴い hcp 構造から蛍石型構造に変態する. La 膜から $\mathrm{LaH}_{x}(x=2)$ へと相変態が起きる際に格子の膨張が起 きる. [0001]の成長方位をとる $\mathrm{La}$ 膜が，水素化によって $\mathrm{LaH}_{x}(2 \leqq x<3)$ の $[111]$ に変態した場合, La 膜はそれぞれの 格子定数から膜の垂直方向に $7.8 \%$, 面内方向に $6.8 \%$ 膨張 することが計算できる．薄膜では膜の垂直方向に拘束力が働 かずこの方向には膨張が起こりやすいと考えられることから， $\mathrm{La}[0001]$ から $\mathrm{LaH}_{x}[111]$ の変態は速やかに起こると考え られる。一方 $\mathrm{La}$ 膜が $[10 \overline{1} 0]$ の成長方位をとる場合, $\mathrm{La}[0001]$ が面に平行にあるため, もしその方位のまま変態 したとすると変態に伴う歪が膜内部に蓄積される．このこと を避けるために $\mathrm{La}$ から $\mathrm{LaH}_{x}$ への変態に伴って方位の回転 が起こると考えられる．このことから La膜が[0001]の成長 方位をとる場合に比べ，La 膜が $[10 \overline{1} 0]$ の成長方位をとる場 合は, $\operatorname{LaH}_{x}(x=2)$ が生成する時間が長くなると考えられ る. 以上の結果より Fig. 2 に抢いて電気抵抗值の増加の振 る舞いが異なっているのは, La 膜の成長方位によるもので あると考えることができる.

Fig. 5 に水素化の進行に伴う La 膜の構造変化を調べるた めに X 線の照射角度を $26 \sim 30$ 度の間で測定を行ったX線回

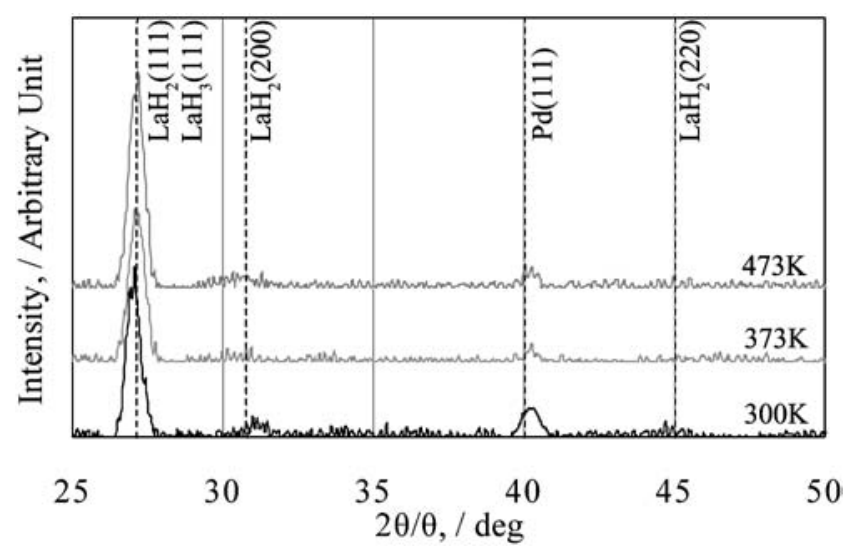

Fig. 3 X-ray diffraction patterns of $\operatorname{LaH}_{x}(2<x<3) / \mathrm{Pd}$ films formed by hydrogen loading of $\mathrm{La} / \mathrm{Pd}$ films. Temperatures of $300 \mathrm{~K}, 373 \mathrm{~K}$ and $473 \mathrm{~K}$ indicated the substrate temperatures during La deposition.

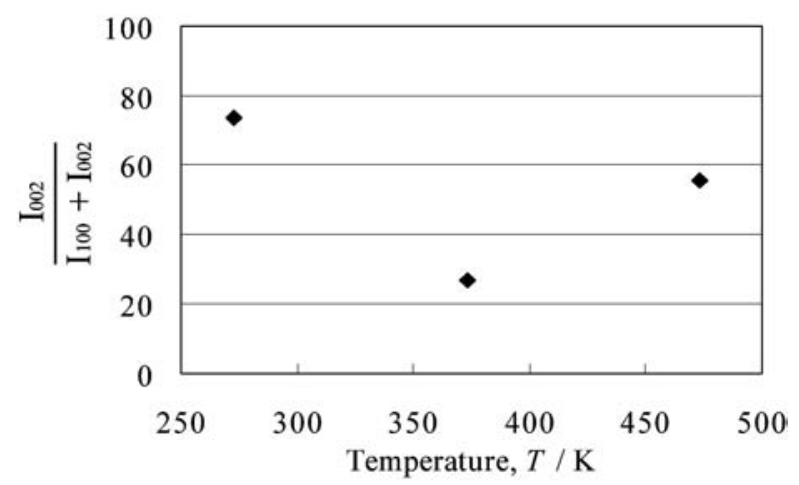

Fig. 4 Substrate temperature dependence of diffraction intensity ratio of $\mathrm{La}(002)$, showing the preferred orientation of $\mathrm{La}$ films.
折パターンを示す. 非常に緩やかな電気抵抗率の変化を示す 基板温度 $373 \mathrm{~K}$ の試料を使用し, Fig. 2 に示す(1), (2)そし て(3)の水素化に対応する時間で測定を行った. 測定を行う際 に, Si の粉末を使用し較正を行った. 今回の X 線回折パ ターンではスムージング $\rightarrow \mathrm{BG}$ 除去 $\rightarrow \mathrm{K} \alpha 2$ 除去とデータ処理

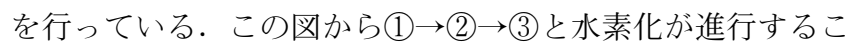
とにより $\mathrm{La}(100)$ の反射が減少し, $\operatorname{LaH}_{x}(0<x \leqq 3)$ の反射が 増加していることがわかる. (1)では $\mathrm{La}(100)$ と $\mathrm{LaH}_{2}(111)$ の反射が現れている. (2)では(1)と比べ $\mathrm{LaH}_{2}(111)$ の反射が 大きくなっている. (3)では $\mathrm{La}(100)$ の反射が消え $\mathrm{LaH}_{x}(x>$

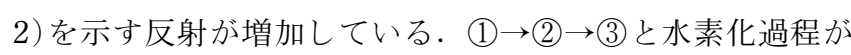
進行することにより反射が現れる角度が高角度側にシフトし ていることがわかる。これは $\mathrm{LaH}_{2}$ の $\mathrm{CaF}_{2}$ 構造の八面体位 置に水素が導入されると, $\mathrm{LaH}_{x}(2 \leqq x<3)$ は $\mathrm{BiF}_{3}$ 構造とな り，格子定数が小さくなることを示している．La膜におけ る水素化過程をX 線回折測定により追跡した例はこれまで に無く, 本実験が初めてである.

Fig. 6 に La/Pd 膜を水素化し, 直ちに液体窒素中に入れ た後, $173 \mathrm{~K} \sim 340 \mathrm{~K}$ の間で昇温・降温を行った時の電気抵 抗率の変化を示す. Fig. 6(a)は基板温度 : 300 K, Fig. 6(b) は基板温度 : $373 \mathrm{~K}, \mathrm{Fig} .6$ (c) は基板温度 : $473 \mathrm{~K}$ の試料を 表している. どの試料に颃いても $\mathrm{La} / \mathrm{Pd}$ 膜の電気抵抗率は 温度が高くなるに従い増加し，金属的な振る舞いを示した。 この振る舞いは酸化保護膜として用いている $\mathrm{Pd}$ の電気伝導 性によると考えられる.すなわち $\mathrm{Pd}$ 膜の電気抵抗率は $\mathrm{LaH}_{x}(2 \leqq x<3)$ 膜に比べ低い為, $\mathrm{Pd}$ 膜の金属的な電気抵抗 特性が強く現れることに起因する．Fig. 6(a), Fig. 6(b), Fig. $6(\mathrm{c})$ のグラフで示した I 点で電気抵抗は急激に減少し た.これと同時に基板温度 $300 \mathrm{~K}$ の試料は透明から鏡面に 変化した。これは $\mathrm{I}$ 点の温度で $\mathrm{LaH}_{x}$ の格子内部から水素が 放出されたためと考えられる. しかし基板温度 $373 \mathrm{~K}, 473$ $\mathrm{K}$ の試料については電気抵抗率の減少は見られたが光を透 過した. 以上の結果から基板温度に関係なく脱水素化反応が 室温付近で容易に起こるが, 基板温度 $373 \mathrm{~K}, 473 \mathrm{~K}$ の試料 は基板温度 $300 \mathrm{~K}$ の試料と比べ $\mathrm{LaH}_{x}$ の内部からの水素の放 出量が少ない. Fig. 6 の (a), (b), (c)のグラフに記載してあ るI とIIの点において X 線回折測定を行った結果を Fig. 7

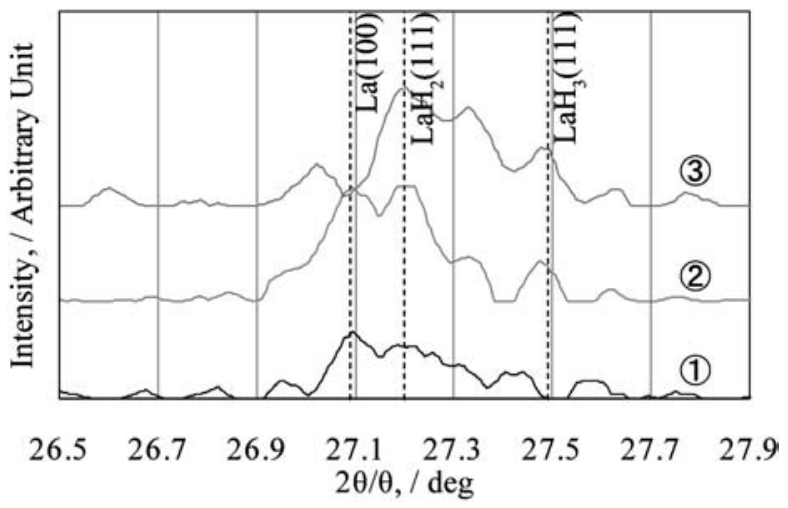

Fig. $5 \mathrm{X}$-ray diffraction pattern during hydrogen loading $\left(P_{\mathrm{H}_{2}}\right.$ $\left.=1.0 \times 10^{5} \mathrm{~Pa}\right)$ for a $\mathrm{La} / \mathrm{Pd}$ film at room temperature in (1), (2) and (3) in Fig. 3. The substrate temperature of this sample was $373 \mathrm{~K}$. 
に示す.

Fig. 7 (a) は基板温度 $300 \mathrm{~K}$ ，(b) は基板温度 $373 \mathrm{~K}$ の試料 である.X 線回折測定は Fig. 5 に示す同様の方法で行っ た. またピークの強度を補正するため保護膜として使用して いる Pdの強度を基準として強度較正を行った. Fig. 7(a)の 基板温度 $300 \mathrm{~K}$ の試料に打いては, 水素化直後の I 点で $\mathrm{LaH}_{x}(2 \leqq x<3)$ を示す高角度側に $\mathrm{X}$ 線反射の強度が分布し ている. しかし脱水素化が完了した II点の強度分布は $\mathrm{LaH}_{2}$ (111)である. 室温で 1 気圧下による脱水素化では, $\mathrm{LaH}_{x}(2$ $<x<3)$ から $\mathrm{LaH}_{2}$ までの相変態が起こり, La までは戻らな いことがわかる．このことから $\mathrm{LaH}_{x}$ が生成することにより 起こる光透過率の変化と電気抵抗率の変化は $\mathrm{LaH}_{2}$ と $\mathrm{LaH}_{x}$ $(x>2)$ の存在する量に関係することがわかる. Fig. $7(\mathrm{~b})$ の 基板温度 $373 \mathrm{~K}$ の試料では基板温度 $300 \mathrm{~K}$ の試料と比べ,

I , II 点での $\mathrm{LaH}_{x}(x>2)$ から $\mathrm{LaH}_{2}$ への変化がわずかであ った. 基板温度 $473 \mathrm{~K}$ 試料も同様であった.

Fig. 8 に I そIの点での $360 \sim 800 \mathrm{~nm}$ の波長の範囲での

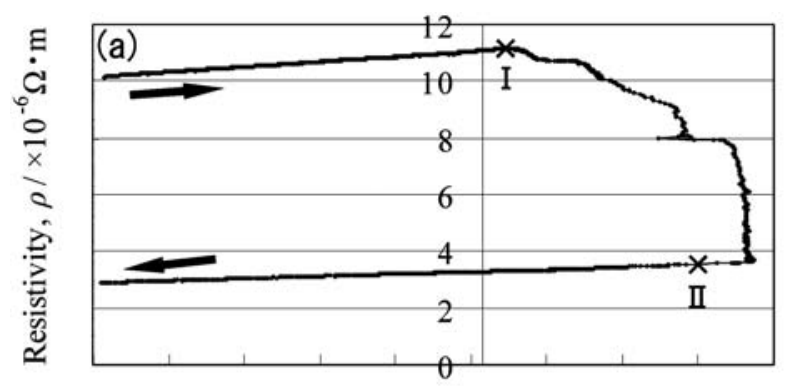

$\begin{array}{llllllllll}170 & 190 & 210 & 230 & 250 & 270 & 290 & 310 & 330 & 350\end{array}$

Temperature, $T / \mathrm{K}$

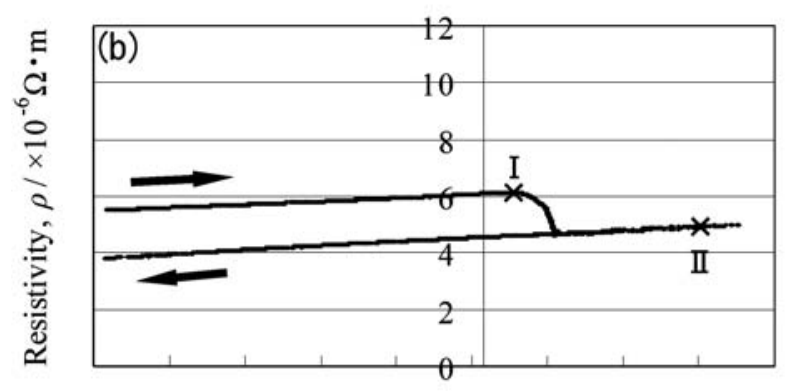

$\begin{array}{llllllllll}170 & 190 & 210 & 230 & 250 & 270 & 290 & 310 & 330 & 350\end{array}$

Temperature, $T$ / K

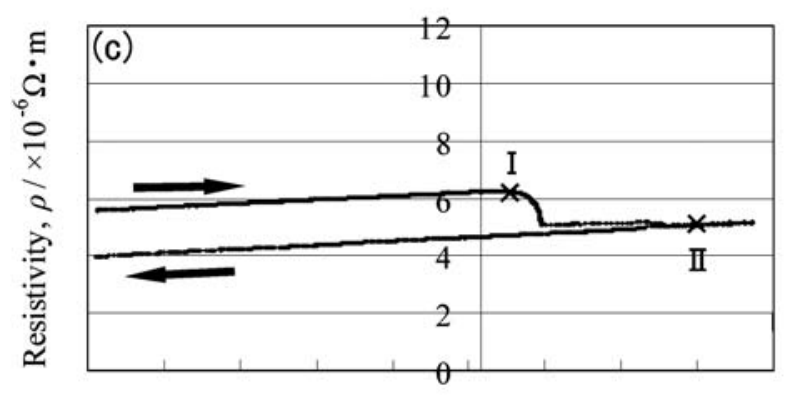

$\begin{array}{llllllllll}170 & 190 & 210 & 230 & 250 & 270 & 290 & 310 & 330 & 350\end{array}$

Temperature, $T$ / K

Fig. 6 Temperature dependence of resistivity of $\mathrm{LaH}_{x} / \mathrm{Pd}$ films formed by hydrogen loading of $\mathrm{La} / \mathrm{Pd}$ films. The substrate temperature during La deposition (a) $300 \mathrm{~K}$, (b) $373 \mathrm{~K}$ and (c) $473 \mathrm{~K}$.
光透過率測定の結果を示す. Fig. 8 (a)が基板温度 $300 \mathrm{~K}$ の 試料, Fig. 8(b) が基板温度 $473 \mathrm{~K}$ の試料を用いた場合の結 果である. 基板温度 $300 \mathrm{~K}$ の試料では透過率が II 点で I 点 と比べると大きな低下を示している. 基板温度 $373 \mathrm{~K}$ の試
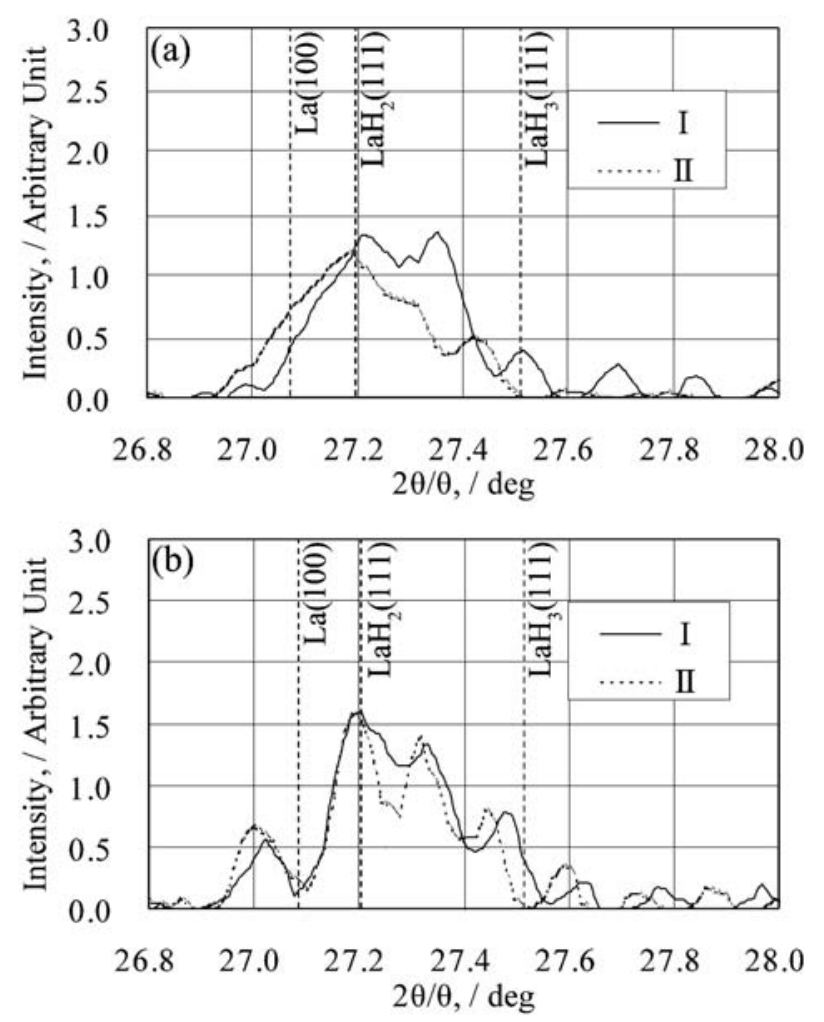

Fig. $7 \mathrm{X}$-ray diffraction patterns at I and II of Fig. 6. (a) substrate temperature $300 \mathrm{~K}$. (b) substrate temperature: $373 \mathrm{~K}$.
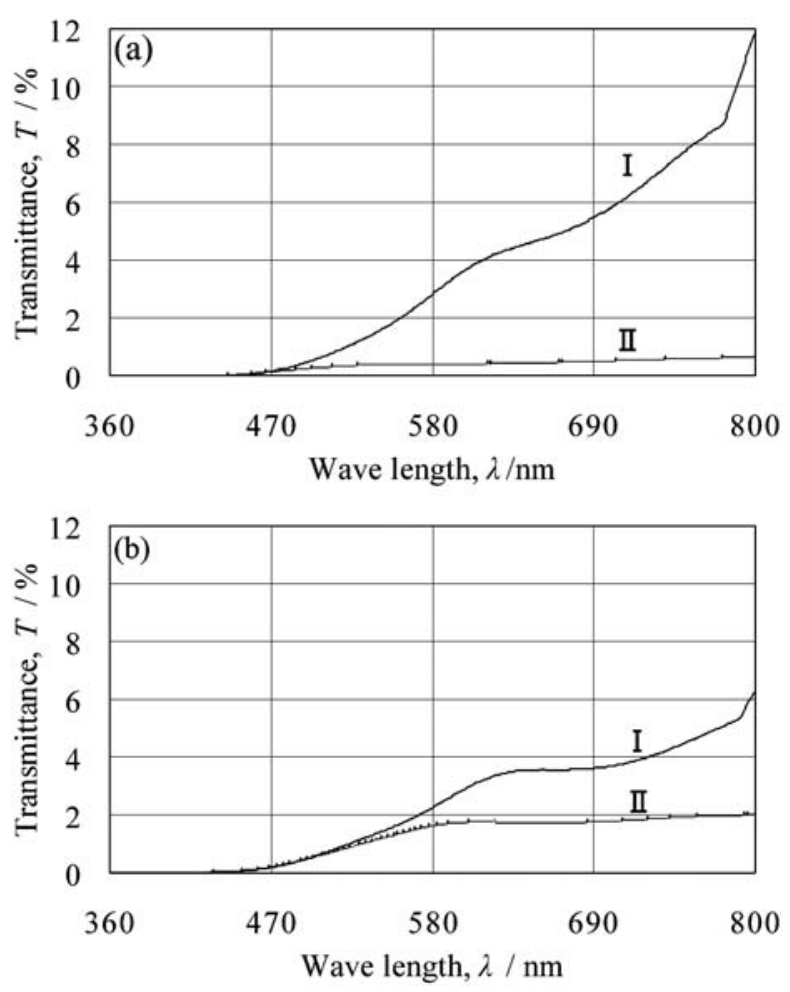

Fig. 8 Optical transmittance at $\mathbf{I}$ and $\mathbf{I I}$ of Fig. 6. (a) substrate temperature $300 \mathrm{~K}$. (b) substrate temperature: $373 \mathrm{~K}$. 


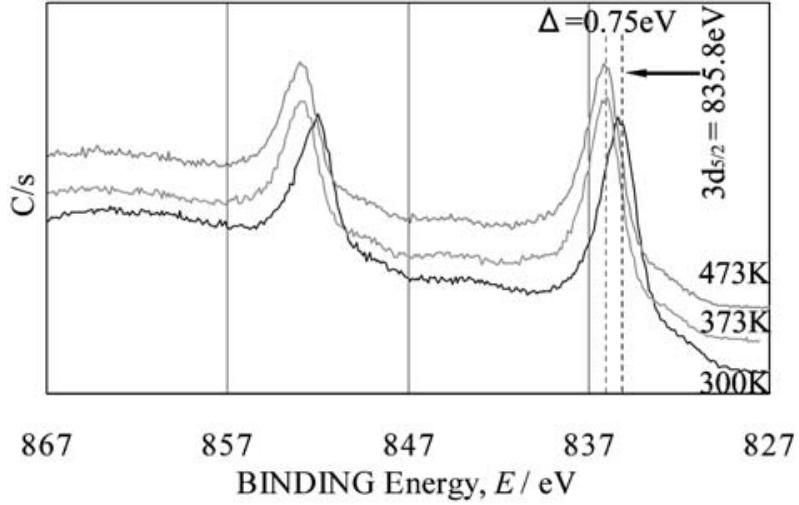

Fig. 9 X-ray photoelectron spectroscopy of $\mathrm{La} / \mathrm{Pd}$ films deposited at the substrate temperature of $300 \mathrm{~K}, 373 \mathrm{~K}$, and $473 \mathrm{~K}$.

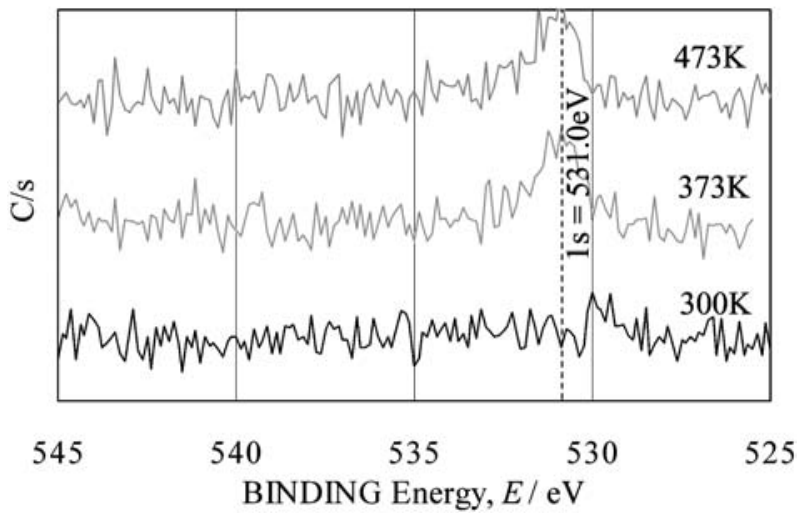

Fig. 10 Measurement of O1s peak in the position of the $\mathrm{La}_{3} \mathrm{~d}_{5 / 2}$ peak using ESCA. The substrate temperature of this sample was $300 \mathrm{~K}, 373 \mathrm{~K}$, and $473 \mathrm{~K}$.

料では基板温度 $300 \mathrm{~K}$ に比べ光透過率の低下は小さいこと がわかる. 基板温度 $473 \mathrm{~K}$ の試料も基板温度 $373 \mathrm{~K}$ の試料 と同様な振る舞いを示した。これら I， II点においての X 線回折測定㧍よび光透過率測定の結果より Fig. 6 の電気抵 抗值の減少の幅は, 水素の $\mathrm{LaH}_{x}(x>2)$ からの放出量に関係 すると考えることができる.すなわち試料作製時の基板温度 が高くなるにつれて水素が抜けにくくなっているということ ができる.

Fig. 9 に基板温度を変化させた場合における La3d ピーク の比較を示す。横軸は結合エネルギーを示している．今回の La のスペクトルはP Pd のスペクトルを利用して較正を行っ ている. 基板温度 $300 \mathrm{~K}$ の試料では $3 \mathrm{~d}_{5 / 2}$ のピークが 835.8 $\mathrm{eV}$ で現れている. 基板温度 $373 \mathrm{~K}, 473 \mathrm{~K}$ の試料では $3 \mathrm{~d}_{5 / 2}$ のピークが高エネルギー側にシフトを起こしている．その差 は約 $0.75 \mathrm{eV}$ であった. La が酸化物を生成すると $3 \mathrm{~d}_{5 / 2}$ の ピークは $832.0 \mathrm{eV}$ 付近へとシフトすることが知られてい る.このことから Fig. 9 のシフトは酸化物の生成によると は考えられない. また Fig. 10 に Fig. 9 のスペクトルを測定 した部分での酸素の $1 \mathrm{~s}$ のピークを示す．この図から非常に わずかではあるが酸素が La 膜内部にあることが確認できる.

Fig. 10 の結果，またその他の元素についての分析からも Fig. 9 の基板温度 $373 \mathrm{~K}, 473 \mathrm{~K}$ ピークのシフトは, 微量な
La 膜に存在する酸素によるものであると考えられる，この 微量の酸素が $\mathrm{La}$ 内部に存在することにより,

(1) La 内部に本来水素が入る位置の所に酸素が存在する.

（2）水素が La 内部に入ってきた際に水素が本来入らなけ ればないところに水素が入ることができない.

（3）水素が La 内部から排出される際に，酸素が存在する ために酸素が無い場合に比べ，水素が抜ける反応が起こりに くくなる.

このためそれぞれの試料を水素化させた際の抵抗值の最大 值が異なる結果となると考えられる。 また基板温度 $300 \mathrm{~K}$ の試料に比べ基板温度 $373 \mathrm{~K}, 473 \mathrm{~K}$ の試料は水素が抜けに くくなると考えられる.

\section{4. 結 論}

$\mathrm{La} / \mathrm{Pd}$ 膜は室温, 1 気圧下で容易に水素化・脱水素化が起 きることがわかった．水素化により $\mathrm{La}$ から $\operatorname{LaH}_{x}(2<x<3)$ まで相変態が起こり, 電気抵抗率は $6 \sim 10$ 倍増加した. 室 温で真空による脱水素化では $\operatorname{LaH}_{x}(2<x<3)$ から $\mathrm{LaH}_{2}$ まで の相変態が起こり, La までは戻らなかった. $\mathrm{La} / \mathrm{Pd}$ 膜の成 長面は $\mathrm{La}(100)$ および $\mathrm{La}(002)$ で基板温度がよりその比が 変化した． La 膜の成長方位で $[10 \overline{1} 0]$ が多い $\mathrm{La} / \mathrm{Pd}$ 膜では, $[0001]$ が多い $\mathrm{La} / \mathrm{Pd}$ 膜より水素化よる電気抵抗率の変化が 一定になるまでの時間が遅くなることがわかった. 水素化後 の $\mathrm{LaH}_{x}(2 \leqq x<3) / \mathrm{Pd}$ 膜の結晶方位は, 水素化前の $\mathrm{La} / \mathrm{Pd}$ 膜の結晶方位に依存することなく $[111]$ となった。これは水 素化に伴う膜内部の歪を小さくする為と考えられる. $\mathrm{La} / \mathrm{Pd}$ 膜内部に酸素が残留すると水素化・脱水素化特性に影響を与 えるということがわかった。

光透過率装置, ESCA を使用させていただいた岩手大学 工学部応用科学科成田研究室および岩手大学地域共同研究セ ンターに感謝いたします。

\section{文献}

1) J. N. Huiberts, R. Griessen, J. H. Rector, R. J. Wijngaarden, J. P. Dekker, D. G. de Groot and N. J. Koeman: Nature (London) 380 (1996) 231.

2) J. N. Huiberts, J. H. Rector, R. J. Wijngaarden, S. Jetten, D. de Groot, B. Dam, N. J. Koeman, R. Griessen, B. Hjörvarsson, S. Olafsson and Y. S. Cho: J. Alloys Compd. 239 (1996) 158.

3) R. Griessen, J. N. Huiberts, M. Kremers, A. T. M van Gogh, N. J. Koeman, J. P. Dekker and P. H. L. Notten: J. Alloys Compd. 253-254(1997) 44.

4) D. G. Nagengast, J. W. J. Kerssemakers, A. T. M. van Gogh, B. Dam and R. Griessen: Appl. Phys. Lett. 1724(12) (1999) 75.

5) A. Rossi: Nature 174(1934) 133.

6) C. G. Titcomb, A. K. Cheetham and B. E. F. Fender: J. Phys. C. Solid State Phys. 2409-2416(1978) 7.

7) G. G. Libowitz and A. J. Maeland: Handbook on the Physics and Chemistry of Rare Earth 299(1979) 4.

8) H. Muller and P. Knappe: ibid 87 (1982) 59

9) C. E. Holley, Jr., R. N. R. Mulford, F. H. Ellinger, W. C. Koehler and W. H. Zachariasen: J. Phys. Chem. 59(1955) 1226.

10) M. Gupta: The Electronic Structure of Complex Systems, NATO ASI Series B, ed. By P. Phariseau, W. M. Temmerman, (Plenum Press, New York, 1983) Vol. 133, p. 243. 